\title{
Candida tropicalis biofilms: Effect on urinary epithelial cells
}

\author{
Melyssa Negri $^{\text {a,b }}$, Sónia Silva ${ }^{a}$, Diogo Breda ${ }^{a}$, Mariana Henriques ${ }^{a}{ }^{*}$, Joana Azeredo ${ }^{a}$, Rosário Oliveira ${ }^{\text {a }}$ \\ ${ }^{a}$ Institute for Biotechnology and Bioengineering, Centre of Biological Engineering, Universidade do Minho, Campus de Gualtar, 4710-057 Braga, Portugal \\ ${ }^{\mathrm{b}}$ Faculdade INGÁ, Curso de Medicina, 87070-000 Maringá, Paraná, Brazil
}

\section{A R T I C L E I N F O}

\section{Article history:}

Received 2 March 2012

Received in revised form 11 May 2012

Accepted 12 May 2012

Available online 22 May 2012

\section{Keywords:}

Candida tropicalis

Biofilm

Artificial urine

Adhesion

Epithelial cells

SAP gene

\begin{abstract}
A B S T R A C T
Candida tropicalis infection is strongly associated with the presence of biofilms in urinary catheters. Thus, the aim of this work was to study the behaviour of $C$. tropicalis in biofilms of different ages (24-120 h) formed in artificial urine (AU) and their effect in human urinary bladder cells (TCC-SUP). Reference strain ATCC 750 and two isolates from patients with candiduria (U69 and U75) were used in this study. The adhesion to human cells was evaluated after $2 \mathrm{~h}$ of contact with Candida biofilms, using the Crystal violet staining method, and the human cells response was evaluated in terms of activity inhibition and cell damage. Candida tropicalis aspartyl proteinase (SAPT) gene expression was determined by real-time PCR. Candida tropicalis biofilm cells were able to adhere to TCC-SUP cells. The highest extent of yeast attachment was obtained for the $72 \mathrm{~h}$ old biofilm cells. Yeasts affected TCC-SUP cells, with 120 h-biofilm cells causing the highest levels of cell injury. Generally, SAPT3 was highly expressed and SAPT4 was only detected in the reference strain. Overall, it is important to highlight that $C$. tropicalis cells detached from biofilms are able to colonize human cells and cause some injury and reduction of metabolic activity.
\end{abstract}

(c) 2012 Elsevier Ltd. All rights reserved.

\section{Introduction}

Candida tropicalis ranks between the second or third nonCandida albicans Candida species (NCAC) most frequently isolated from patients with Candida infections [1,2]. According to epidemiological data, $C$. tropicalis has been related with urinary tract infections and haematological malignancy [1,2]. Furthermore, the most important causes of $C$. tropicalis candiduria are associated with antibiotic therapy and indwelling catheterization $[3,4]$.

Several virulence factors seem to be responsible for $C$. tropicalis infections, which present higher potential for dissemination and mortality in patients admitted in intensive care units (ICUs) than C. albicans or any other NCAC species [4]. Included in these virulence factors are: their ability to adhere and to form biofilms onto different indwelling medical devices; their capacity to adhere, invade and damage host human tissues due to enzymes production such as proteinases [4-7].

It is known that Candida biofilms have strategies to be more resistant to antifungal agents and more virulent than the corresponding planktonic cells [8]. Moreover, recent studies showed the capacity of Candida cells or biofilm parts to detach from a biofilm and to colonize distal sites, being able to disperse into the host

\footnotetext{
* Corresponding author. Tel.: +351 253604408; fax: +351 253678986.

E-mail address: mcrh@deb.uminho.pt (M. Henriques).
}

environment and adhere to endothelial or epithelial cells and initiating an infection [9]. However, there is little knowledge about the effect of $C$. tropicalis biofilms on epithelial cells. Thus, the aim of this work was to study the behaviour of $C$. tropicalis biofilms, formed in the presence of artificial urine, and their effect in bladder cells.

\section{Material and methods}

\subsection{Candida tropicalis and growth conditions}

Three strains of $C$. tropicalis were used in this study, one reference strain from the American Type Culture Collection (ATCC 750) and two clinical isolates (U69 and U75) obtained from patients with candiduria admitted to the intensive care unit and belonging to the archive collection of the University Hospital in Maringá, Paraná, Brazil. For each experiment, strains were subcultured on Sabouraud dextrose agar (SDA; Merck, Darmstadt, Germany) for $48 \mathrm{~h}$ at $37^{\circ} \mathrm{C}$. Yeast cells were then inoculated in Sabouraud dextrose broth (SDB; Merck) and incubated for $18 \mathrm{~h}$ at $37^{\circ} \mathrm{C}$ under agitation in an orbital shaker (120 rev/min). After incubation, yeast cells were harvested by centrifugation at $8000 \times \mathrm{g}$ for $5 \mathrm{~min}$ at $4{ }^{\circ} \mathrm{C}$ and washed twice with Phosphate Buffer Solution (PBS; pH 7.5; $0.01 \mathrm{~mol} \mathrm{~mL}^{-1}$ ). The remaining pellets were suspended in artificial urine (AU) and the cellular density adjusted to $1 \times 10^{7}$ yeasts $\mathrm{mL}^{-1}$, using a Neubauer chamber. Artificial urine ( $\mathrm{pH}$ 5.8) was prepared according to Silva et al. [6]. 


\subsection{Candida tropicalis planktonic cells}

After adjust the cellular density in AU, planktonic cells were incubated for $24 \mathrm{~h}$ at $37{ }^{\circ} \mathrm{C}$ under agitation in an orbital shaker (120 rev/min). Then, planktonic cells were harvested by centrifugation at $8000 \times \mathrm{g}$ for $5 \mathrm{~min}$ at $4{ }^{\circ} \mathrm{C}$ and the pellets were suspended in D-MEM without Penicilyn/Streptomycin $(\mathrm{P} / \mathrm{S})$ and the cellular density adjusted to $1 \times 10^{7}$ yeasts $\mathrm{mL}^{-1}$, using a Neubauer chamber.

\subsection{Candida tropicalis biofilms formation}

Biofilms, with different ages of maturation (24, 48, 72, 96 and $120 \mathrm{~h}$ ), were formed on silicone coupons $\left(1 \times 1 \mathrm{~cm}^{2}\right)$ according to Silva et al. [6]. After the defined times of incubation, the medium was aspirated and non-adherent $C$. tropicalis cells were removed by washing the silicone coupons with PBS.

\subsection{Human urinary bladder epithelial cell line}

The cell line TCC-SUP, derived from human urinary bladder epithelial cells (DSMZ - German Collection of Microorganisms and Cell Cultures) was used as model for analysing the colonization by C. tropicalis cells when in contact with their biofilms. The cells were cultured and the 24-well plate containing human cells monolayers, prior to adhesion assay, were prepared according to Negri et al. [10].

\subsection{Candida tropicalis biofilms and planktonic cells in contact with TCC-SUP cells}

The silicone coupons containing biofilms were removed from the wells, carefully inverted and immediately put in contact with the pre-formed monolayer of TCC-SUP cells and $1 \mathrm{~mL}$ of D-MEM without $\mathrm{P} / \mathrm{S}$ was added to each well. For planktonic cells, $1 \mathrm{~mL}$ of medium (D-MEM without $\mathrm{P} / \mathrm{S}$ ) with planktonic cells was put in contact with the pre-formed monolayer of TCC-SUP cells. After $2 \mathrm{~h}$ of contact at $37{ }^{\circ} \mathrm{C}$ under $5 \% \mathrm{CO}_{2}$, the coupons containing the biofilms and the suspension with planktonic cells were removed, then, each well washed once with PBS. The remaining yeasts attached to the monolayer were quantified using the CV staining method, according to Negri et al. [11]. The mean absorbance of yeasts was expressed as the absorbance per area of each well and standardized by the number of adhered yeasts per area of each well using C. tropicalis standard curve [11]. All the procedures were repeated in triplicate in at least three separate assays.

\subsection{Effect of $C$. tropicalis on TCC-SUP cells}

\subsubsection{Determination of epithelial cells damage assay}

After the removal of the coupons, the release of lactate dehydrogenase (LDH) by epithelial cells into the culture medium was used as a measure of cell damage, using the CytoTox-ONE ${ }^{\mathrm{TM}}$ kit (Promega, Madison, USA) following the manufacturer's instructions. The LDH activity was analysed according to Negri et al. [10]. All experiments were performed in triplicate and in three separate occasions.

\subsubsection{Determination of epithelial cells activity}

After the removal of the coupons and the washing step with PBS, the remaining adhered yeasts were killed according to Negri et al. [10], and the CellTiter $96^{\circledR}$ assay ([3-(4,5-dimethylthiazol-2-yl)-5(3-carboxymethoxyphenyl)-2-(4-sulfophenyl)-2H-tetrazolium], MTS; Promega, USA) was used to determine the TCC-SUP cells activity. All the procedures were repeated in triplicate in at least three separate assays.

\subsection{Analysis of SAP gene expression}

\subsubsection{RNA extraction}

After 2 h of TCC-SUP cells infectivity with biofilms or planktonic cells and the washing step with PBS, $C$. tropicalis cells attached to TCC-SUP cells were scrapped from the 24 -well plate into $500 \mu \mathrm{L}$ of lysis buffer. The yeast cells were disrupted according to Negri et al. [10], the PureLink ${ }^{\mathrm{TM}}$ RNA Mini kit (Invitrogen) was used for total RNA extraction according to the manufacturer's recommended protocol. To avoid potential DNA contamination the samples were treated with RNase-Free DNase I (Invitrogen).

\subsubsection{Primers, synthesis of $C D N A$ and real-time $P C R$}

The primers used for real-time PCR (RT-PCR) are described in Silva et al. [5] and their sequence is listed on Table 1 . The relative quantification of SAPT1-4 gene expression was performed by the $\Delta C_{T}$ method. Each reaction was performed in triplicate and mean values of relative expression were analysed for each SAP gene.

\subsection{Statistical analysis}

The results obtained were analysed using the SPSS 18 (Statistical Package for the Social Sciences) program. One-way ANOVA with the Bonferroni test was used in these tests. All tests were performed with a confidence level of $95 \%$. All the experiments were performed in triplicate and in three independent assays.

\section{Results}

\subsection{Candida tropicalis biofilms in contact with TCC-SUP cells}

All $C$. tropicalis biofilm yeast cells were able to adhere to TCCSUP cells independently of the biofilm age (Fig. 1). Nevertheless, there were slightly differences in $C$. tropicalis adhesion ability to TCC-SUP cells, namely, the highest number of attached yeast cells was obtained for the $72 \mathrm{~h}$-biofilm from isolate U75 and the lowest occurred for the 120 h-biofilm from isolate U69 $(P<0.05)$. The latter strain (U69) showed a higher variation in the profile of adhesion extent compared to the other two strains.

In general, $C$. tropicalis biofilm cells affected TCC-SUP cells after $2 \mathrm{~h}$ of contact (Table 2), and in a similar way for the three strains. It is important to highlight that TCC-SUP cells exhibited the highest $(P<0.05)$ percentage of damage after contact with $96 \mathrm{~h}$-biofilm U75 cells and with 120 h-biofilms from strains U69 and ATCC 750. Overall, no direct correlation was observed between the profile of TCC-SUP cells damage and activity inhibition caused by the different $C$. tropicalis biofilms. For instance, the human cells response induced by $72 \mathrm{~h}$-biofilms is contradictory once there was a decrease in cell activity inhibition, but an increase in cell damage $(P<0.05)$. However, it is interesting to notice that when human

Table 1

Primers used for real-time PCR analysis of SAP and control gene expression.

\begin{tabular}{|c|c|c|c|}
\hline Sequence $\left(5^{\prime} \rightarrow 3^{\prime}\right)$ & Primer & Target & $\begin{array}{l}\text { PCR product } \\
\text { size (bp) }\end{array}$ \\
\hline GGAAGATCTGATGTGCCAACTACATTGA & Forward & SAPT1 & 1005 \\
\hline CGTGCGGCCGCTCTACAAAGCCGAGATGTCT & Reverse & & \\
\hline TTCTTCTAGTGGTACCTGGGTCAAAG & Forward & SAPT2 & 762 \\
\hline CATAGATCTCTAAACAATAGTGACATTAGA & Reverse & & \\
\hline ACTTGGATTTCCAGCGAAGA & Forward & SAPT3 & 165 \\
\hline AGCCCTTCCAATGCCTAAAT & Reverse & & \\
\hline GTACTCGAGCTCCTACAACTTCACСТCCT & Forward & SAPT4 & 1130 \\
\hline CATGGATCCCTATGTAAGTGGAAGTATGTT & Reverse & & \\
\hline GACCGAAGCTCCAATGAATC & Forward & ACT1 & 181 \\
\hline AATTGGGACAACGTGGGTAA & Reverse & & \\
\hline
\end{tabular}




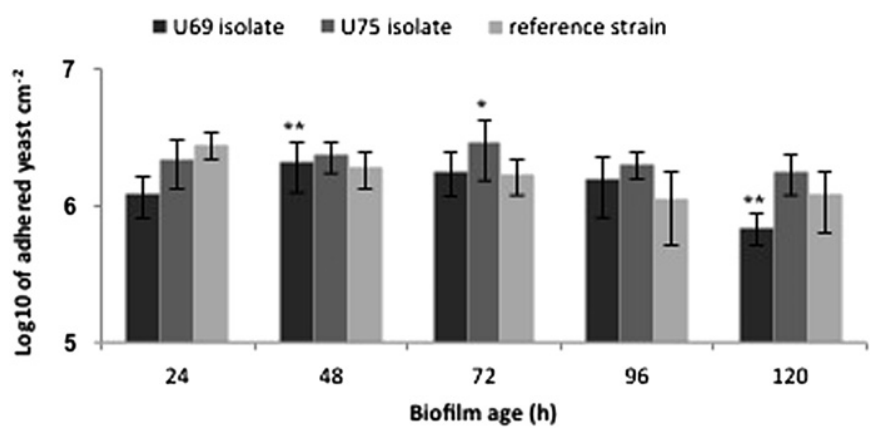

Fig. 1. Number of Candida tropicalis from different biofilms time point attachment to human epithelial cells. * Statistical difference among strains $(P<0.05) ;{ }^{* *}$ Statistical differences from 24 to $48 \mathrm{~h}$ and $96 \mathrm{~h}$ to $120 \mathrm{~h}$ of U69 isolate biofilms' time points $(P<0.05)$.

cells injury caused by biofilms (120 h-biofilm of strain U69) was more notorious, both tests were concordant, $P<0.05$, (50.0\% and $27.7 \%$ of cell damage and inhibition of cellular activity, respectively).

\subsection{Candida tropicalis SAP gene expression}

Analysing C. tropicalis SAP gene expression (Table 3) when in contact with TCC-SUP cells, it can be noticed that $C$. tropicalis suspended cells grown in AU were not able to express SAPT1 gene. However, when grown in the sessile form, strains U69 and ATCC 750 from 48 h-biofilms were able to express SAPT1. As regards SAPT2 gene expression, for U69 and ATCC 750 strains from 24 to 48 h-biofilms and U75 from 120 h-biofilms, SAPT2 was detected in similar amount.

In opposition to the other SAPT genes, SAPT3 was expressed and in the great majority of situations.

Interestingly, SAPT4 was only expressed by the reference strain, and in few situations (adhered yeasts grown in suspension and from 24 h-biofilms).

\section{Discussion}

It is known that during the development of Candida biofilms, some dispersion/detachment of cells or dissolution of biofilm

\section{Table 2}

Percentage of cell activity inhibition and damage evaluated by MTS and LDH, respectively, after Candida tropicalis adhesion to human TCC-SUP cell line. $P$ values obtained from the comparison among the three strains and among biofilms with different ages $(24,48,72,96$ and $120 \mathrm{~h}$ ) are also presented.

\begin{tabular}{|c|c|c|c|c|}
\hline \multirow[t]{2}{*}{ Reaction } & \multirow[t]{2}{*}{ Time (h) } & \multicolumn{3}{|l|}{ Isolate } \\
\hline & & U69 & U75 & Reference \\
\hline \multirow{5}{*}{$\begin{array}{l}\text { \% Activity inhibition } \\
\text { (MTS) }\end{array}$} & 24 & $16.0 \pm 2.4$ & $11.0 \pm 1.6$ & $5.2 \pm 1.6^{\mathrm{a}}$ \\
\hline & 48 & $16.6 \pm 2.4$ & $15.9 \pm 3.6^{\mathrm{b}}$ & $19.5 \pm 4.4^{\mathrm{b}}$ \\
\hline & 72 & $8.7 \pm 2.4^{b}$ & $4.5 \pm 1.1^{\mathrm{b}}$ & $5.9 \pm 1.6^{\mathrm{b}}$ \\
\hline & 96 & $9.6 \pm 0.9$ & $8.7 \pm 1.4$ & $10.4 \pm 2.8$ \\
\hline & 120 & $27.7 \pm 3.4^{\mathrm{a}, \mathrm{b}}$ & $7.7 \pm 1.6$ & $6.1 \pm 0.8$ \\
\hline \multirow{5}{*}{ \% Damage (LDH) } & 24 & $9.0 \pm 2.6$ & $14.8 \pm 4.1$ & $8.3 \pm 1.6$ \\
\hline & 48 & $12.3 \pm 2.6$ & $14.1 \pm 3.5$ & $14.8 \pm 1.0$ \\
\hline & 72 & $25.4 \pm 4.6^{\mathrm{b}}$ & $18.4 \pm 3.5^{\mathrm{b}}$ & $18.8 \pm 2.9^{b}$ \\
\hline & 96 & $7.4 \pm 1.1^{\mathrm{b}}$ & $26.6 \pm 4.9^{\mathrm{a}, \mathrm{b}}$ & $12.4 \pm 2.3$ \\
\hline & 120 & $50.0 \pm 10.5^{b}$ & $20.6 \pm 1.3^{\mathrm{a}}$ & $40.3 \pm 5.0^{\mathrm{b}}$ \\
\hline
\end{tabular}

All values are means \pm Standard deviations.

${ }^{a}$ Effect on human epithelial cells statistically different from the other strains $(P<0.05)$.

b Effect of biofilm age on human epithelial cells statistically different from the others $(P<0.05)$. pieces can occur [7,9]. This is an important phenomenon, since the dispersed and detached cells could be responsible for the subsequent establishment of disseminated candidiasis at distal organs $[9,12]$. Thus, it is extremely relevant to study the ability of C. tropicalis cells detached from pre-formed biofilms to colonize human epithelial cells and the consequent degree of damage.

All C. tropicalis biofilms (independently of their age) were able to detach and colonize TCC-SUP cells (Fig. 1), although in a strain dependent way. Other studies have shown that $C$. tropicalis planktonic cells extent of adhesion to human cells is also strain specific $[5,10,13,14]$.

It is interesting to highlight that biofilm yeast cells adhered to TCC-SUP cells (Fig. 1) in a similar extent of their planktonic counterparts [14]. Uppuluri et al. [9] reported a different behaviour for C. albicans adhesion to endothelial cells, since yeast cells dispersed from biofilms adhered in larger numbers than planktonic ones. Maybe, this fact can be related with differences between the two yeast species or the differences between the human cells used, which determine very specific interactions with yeast cells $[15,16]$.

Human cells damage is reported to be dependent on the contact time and yeast infectivity rate [5,9]. Overall, the present results point out that older biofilms ( $96 \mathrm{~h}$ or $120 \mathrm{~h}$ ) induced higher cell damage (Table 2) than younger ones, however in a strain dependent manner. Therefore, these data highlight the virulence potential of $C$. tropicalis cells dispersed from biofilms, since they seem to be a causative agent of an increased LDH release by TCC-SUP cells.

Opportunistic yeast pathogens, such as $C$. tropicalis, are able to promote cell host immune response and progressive cell damage during infection $[5,13,17]$. However, in this study no direct correlation was observed between cell damage and inhibition of cellular activity, namely adhered yeast cells from $72 \mathrm{~h}$-biofilm induced high damage but a low extent of inhibition of cell activity. Nevertheless, it is very interesting to notice that when the inhibition of cellular activity was significantly higher (for U69 120 h-biofilm) cell damage was also the highest. This underlines that these two factors are only in direct relation when the degree of injury is very high. The lack of a direct relation between cell activity inhibition and cell damage at low levels of injury can be explained by the fact that, during the first stage of human cells colonization by Candida, the cellular defence mechanisms are initiated, which may cause an increase of metabolic activity before the onset of any damage [17-19].

It has been widely reported that, during the adhesion and invasion processes of host tissues, Candida species are able to secrete hydrolytic enzymes that cause damage on host cells membrane integrity, leading to dysfunction or disruption of host structures [20,21]. Candida secreted aspartyl proteinases (SAPs) have been associated with tissue invasion and their secretion is also associated with the inflammatory host response [22]. Additionally, the expression of SAP genes by C. tropicalis (SAPT1-SAPT4) has been associated to the dissemination of infection and evasion from macrophages after yeast cells phagocytosis [5,20,23].

Real-time PCR analysis (Table 3 ) revealed that SAPT gene expression by $C$. tropicalis, grown in AU (in planktonic and biofilm form), and colonizing TCC-SUP cells showed, in general, a higher level for SAPT3 expression followed by lower levels of SAPT2, SAPT1 and SAPT4. These features were similar to those described by Silva et al. [5] who studied the expression profiles of SAP genes by seven C. tropicalis strains in contact with reconstituted human oral epithelium: all strains also expressed the 4 genes (SAPT1 - 4), moreover SAPT2 and SAPT4 transcripts were detected in a similar extent to SAPT3 and the majority of strains did not express SAPT1. Similarly, in the present study, only two strains (U69 and ATCC 750 strains) from 48 h-biofilms were able to express SAPT1, but in planktonic form this gene expression was not detected. 
Table 3

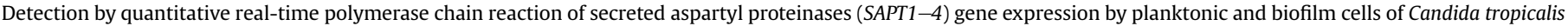
when adhered to the human epithelial TCC-SUP cell line.

\begin{tabular}{|c|c|c|c|c|c|}
\hline \multirow[t]{2}{*}{ Strain } & \multirow[t]{2}{*}{ C. tropicalis form } & \multicolumn{4}{|c|}{ Relative expression of $S A P$ genes $^{\mathrm{a}}$} \\
\hline & & SAP1 & SAP2 & SAP3 & SAP4 \\
\hline \multirow[t]{6}{*}{ U69 isolate } & Planktonic & ND & $0.01 \pm 0.00$ & $2.24 \pm 0.32$ & ND \\
\hline & Biofilm $24 \mathrm{~h}$ & ND & ND & $0.24 \pm 0.16$ & ND \\
\hline & Biofilm $48 \mathrm{~h}$ & $0.01 \pm 0.00$ & $0.01 \pm 0.00$ & $2.38 \pm 0.15$ & ND \\
\hline & Biofilm $72 \mathrm{~h}$ & ND & $0.02 \pm 0.00$ & $0.87 \pm 0.06$ & ND \\
\hline & Biofilm $96 \mathrm{~h}$ & ND & ND & $0.10 \pm 0.03$ & ND \\
\hline & Biofilm $120 \mathrm{~h}$ & ND & ND & $0.21 \pm 0.05$ & ND \\
\hline \multirow[t]{6}{*}{ U75 isolate } & Planktonic & ND & ND & $0.17 \pm 0.05$ & ND \\
\hline & Biofilm $24 \mathrm{~h}$ & ND & ND & $0.12 \pm 0.09$ & ND \\
\hline & Biofilm $48 \mathrm{~h}$ & ND & ND & $0.26 \pm 0.08$ & ND \\
\hline & Biofilm $72 \mathrm{~h}$ & ND & ND & $0.26 \pm 0.06$ & ND \\
\hline & Biofilm $96 \mathrm{~h}$ & ND & ND & $0.31 \pm 0.09$ & ND \\
\hline & Biofilm $120 \mathrm{~h}$ & ND & $0.01 \pm 0.00$ & $0.56 \pm 0.31$ & ND \\
\hline Reference strain & Planktonic & ND & ND & $0.01 \pm 0.00$ & $0.02 \pm 0.00$ \\
\hline \multirow[t]{5}{*}{ ATCC 750} & Biofilm $24 \mathrm{~h}$ & ND & $0.01 \pm 0.00$ & $0.18 \pm 0.05$ & $3.04 \pm 0.00$ \\
\hline & Biofilm $48 \mathrm{~h}$ & $0.18 \pm 0.00$ & $0.01 \pm 0.00$ & $0.34 \pm 0.06$ & ND \\
\hline & Biofilm $72 \mathrm{~h}$ & ND & ND & $0.40 \pm 0.01$ & ND \\
\hline & Biofilm $96 \mathrm{~h}$ & ND & ND & $0.49 \pm 0.14$ & ND \\
\hline & Biofilm $120 \mathrm{~h}$ & ND & ND & $0.21 \pm 0.16$ & ND \\
\hline
\end{tabular}

$\mathrm{ND}$, indicates that no gene expression was detected.

${ }^{\text {a }}$ Mean arbitrary messenger RNA transcript levels based upon triplicate measurements, presented as a percentage relative to the respective ACT1 transcript level.

Furthermore, the high expression of SAPT3 points out its importance in the pathogenesis of $C$. tropicalis strains under these conditions.

In order to confer maximum benefits for Candida pathogenicity SAP genes family are activated efficiently and in flexible way at specific time points during colonization and infection processes. Moreover, SAP genes expression is strongly correlated with environment where Candida is grown $[21,23,24]$. In the present study there is a different gene expression among the different modes of growth. For instance, although adhered $C$. tropicalis from biofilms (Reference strain from 24 to 48 h-biofilms and U75 from 120 hbiofilm) exhibited SAPT2 expression, adhered yeasts from planktonic form did not express this gene. Curiously, SAPT4 was only detected in ATCC 750 from specific biofilm ages. Other studies indicate that there is an optimum $\mathrm{pH}$ for $C$. tropicalis-secreted aspartic proteinases activity, therefore making SAP gene expression strain and epithelium dependent [5,20,23]. It is important to highlight that there are only few studies reporting $C$. tropicalis SAPT genes expression during the adhesion to human cells. This could suggest that Saps do not play a significant role in the reduction of epithelial cells activity and damage caused by $C$. tropicalis strains.

In summary, the present study shows that $C$. tropicalis from biofilms are able to colonize human cells and cause some injury: damage and reduction of metabolic activity. Moreover, it is important to highlight that $C$. tropicalis SAP genes are expressed by cells adhered to epithelium, either from planktonic growth or biofilms. Furthermore, to our knowledge, this is the first report of C. tropicalis SAP genes expression when biofilm cells colonize TCCSUP cells, and the results imply a limited role of these enzymes in human cells damage and metabolic activity reduction in the conditions assayed. Nevertheless, SAPT3 transcript presented the highest level of gene expression by $C$. tropicalis assayed, regardless of biofilm age. However, more studies have to be performed to clarify if these $C$. tropicalis SAPs genes are associated with C. tropicalis virulence potential.

\section{Acknowledgements}

The authors acknowledge Coordenação de Aperfeiçoamento de Pessoal de Nível Superior (CAPES), Brazil, for supporting Melyssa Negri (BEX 4642/06-6) and Fundação para a Ciência e Tecnologia
(FCT), Portugal, for supporting Sonia Silva (SFRH/BPD/71076/2010), and European Community fund FEDER, through Program COMPETE, in the ambit of the Project FCOMP-01-0124-FEDER007025 (PTDC/AMB/68393/2006) is gratefully acknowledged.

\section{References}

[1] Nucci M, Queiroz-Telles F, Tobon AM, Restrepo A, Colombo AL. Epidemiology of opportunistic fungal infections in Latin America. Clin Infect Dis 2010;51: 561-70.

[2] Falagas ME, Roussos N, Vardakas KZ. Relative frequency of albicans and the various non-albicans Candida spp among candidemia isolates from inpatients in various parts of the world: a systematic review. Int J Infect Dis 2010;14: 954-66.

[3] Munoz P, Giannella M, Fanciulli C, Guinea J, Valerio M, Rojas L, et al. Candida tropicalis fungaemia: incidence, risk factors and mortality in a general hospital. Clin Microbiol Infect 2011;17:1538-45.

[4] Kothavade RJ, Kura MM, Valand AG, Panthaki MH. Candida tropicalis: its prevalence, pathogenicity and increasing resistance to fluconazole. J Med Microbiol 2010;59:873-80.

[5] Silva S, Hooper SJ, Henriques M, Oliveira R, Azeredo J, Williams DW. The role of secreted aspartyl proteinases in Candida tropicalis invasion and damage of oral mucosa. Clin Microbiol Infect 2011;17:264-72.

[6] Silva S, Negri M, Henriques M, Oliveira R, Williams D, Azeredo J. Silicone colonization by non-Candida albicans Candida species in the presence of urine. J Med Microbiol 2010;59:747-54.

[7] Negri M, Silva S, Henriques M, Azeredo J, Svidzinski T, Oliveira R. Candida tropicalis biofilms: artificial urine, urinary catheters and flow model. Med Mycol 2011;49:739-47.

[8] Silva S, Negri M, Henriques M, Oliveira R, Williams DW, Azeredo J. Adherence and biofilm formation of non-Candida albicans Candida species. Trends Microbiol 2011;19:241-7.

[9] Uppuluri P, Chaturvedi AK, Srinivasan A, Banerjee M, Ramasubramaniam AK, Köhler JR, et al. Dispersion as an important step in the Candida albicans biofilm developmental cycle. PLoS Pathog 2010;6:e1000828.

[10] Negri M, Botelho C, Silva S, Lopes LM, Henriques M, Azeredo J, et al. An in vitro evaluation of Candida tropicalis infectivity using human cell monolayers. J Med Microbiol 2011;60:1270-5.

[11] Negri M, Gonçalves V, Silva S, Henriques M, Azeredo J, Oliveira R. Crystal violet staining to quantify Candida adhesion to epithelial cells. Br J Microbiol 2010; 67:120-5.

[12] Sellam A, Al-Niemi T, McInnerney K, Brumfield S, Nantel A, Suci P. A Candida albicans early stage biofilm detachment event in rich medium. BMC Microbiol 2009;9:25.

[13] Okawa Y, Miyauchi M, Kobayashi H. Comparison of pathogenicity of various Candida tropicalis strains. Biol Pharm Bull 2008;31:1507-10.

[14] Negri M, Martins M, Henriques M, Svidzinski T, Azeredo J, Oliveira R. Examination of potential virulence factors of Candida tropicalis clinical isolates from hospitalized patients. Mycopathologia 2010;169:175-82.

[15] Bendel CM. Colonization and epithelial adhesion in the pathogenesis of neonatal candidiasis. Semin Perinatol 2003;27:357-64. 
[16] Sohn K, Senyürek I, Fertey J, Königsdorfer A, Joffroy C, Hauser N, et al. An in vitro assay to study the transcriptional response during adherence of Candida albicans to different human epithelia. FEMS Yeast Res 2006;6: 1085-93.

[17] Saegusa S, Totsuka M, Kaminogawa S, Hosoi T. Cytokine responses of intestinal epithelial-like Caco-2 cells to non-pathogenic and opportunistic pathogenic yeasts in the presence of butyric acid. Biosci Biotechnol Biochem 2007; 71:2428-34.

[18] Wang L, Sun J, Horvat M, Koutalistras N, Johnston B, Ross Sheil AG. Evaluation of MTS, XTT, MTT and3HTdR incorporation for assessing hepatocyte density, viability and proliferation. Methods Cell Sci 1996;18:249-55.

[19] van de Veerdonk FL, Kullberg BJ, Netea MG. Pathogenesis of invasive candidiasis. Curr Opin Crit Care 2010;16:453-9.
[20] Zaugg C, Borg-von Zepelin M, Reichard U, Sanglard D, Monod M. Secreted aspartic proteinase family of Candida tropicalis. Infect Immun 2001;69: 405-12.

[21] Naglik JR, Albrecht A, Bader O, Hube B. Candida albicans proteinases and host/ pathogen interactions. Cell Microbiol 2004;6:915-26.

[22] Yang Y. Virulence factors of Candida species. J Microbiol Immunol Infect 2003; 36:223-8.

[23] Togni G, Sanglard D, Falchetto R, Monod M. Isolation and nucleotide sequence of the extracellular acid protease gene (ACP) from the yeast Candida tropicalis. FEBS Lett 1991;286:181-5.

[24] Naglik JR, Challacombe SJ, Hube B. Candida albicans secreted aspartyl proteinases in virulence and pathogenesis. Microbiol Mol Biol Rev 2003;67: 400-28. 